\title{
Sediment Carbon Accumulation in Southern Latitude Saltmarsh Communities of Tasmania, Australia
}

\author{
Joanna C. Ellison $1, *\left(\mathbb{D}\right.$ and Kim M. Beasy ${ }^{2}$ \\ 1 Discipline of Geography and Spatial Sciences, School of Technology, Environments and Design, \\ University of Tasmania, Launceston, Tasmania 7250, Australia \\ 2 School of Education, University of Tasmania, Launceston, Tasmania 7250, Australia; Kim.Beasy@utas.edu.au \\ * Correspondence: Joanna.Ellison@utas.edu.au; Tel.: +61-3-6324-3834
}

Received: 23 November 2017; Accepted: 26 April 2018; Published: 2 May 2018

\begin{abstract}
Carbon sequestration values of wetlands are greatest in their sediments. Northern hemisphere research dominates the earlier saltmarsh carbon sequestration literature, recently augmented by analyses across mainland Australia where species assemblages, catchment histories and environmental settings differ. No previous assessment has been made for Tasmania. Carbon stores and accumulation rates in saltmarsh sediments of the Rubicon estuary, Tasmania, were investigated. Carbon was determined from sediment cores by Elemental Analyser, combined with analysis of organic content and bulk density. Carbon accumulation was determined using short-term and long-term sediment accretion indicators. Results showed carbon densities to be lower than global averages, with variation found between carbon stores of native and introduced species zones. Cores from introduced Spartina anglica indicated a trend of higher sediment carbon percentages relative to cores from native saltmarsh Juncus kraussii and Sarcocornia quinqueflora, and in finer grain sizes. Sediment carbon stock of $30 \mathrm{~cm}$ depths was $49.5 \mathrm{MgC} \mathrm{ha}^{-1}$ for native saltmarsh and $55.5 \mathrm{MgC} \mathrm{ha}^{-1}$ for Spartina. Carbon percentages were low owing to high catchment inorganic sediment yields, however carbon accumulation rates were similar to global averages, particularly under Spartina. Covering $85 \%$ of saltmarsh area in the estuary, Spartina contributes the majority to carbon stores, potentially indicating a previously unrecognized value for this invasive species in Australia.
\end{abstract}

Keywords: saltmarsh; sediment carbon; wetland; accumulation rates; Spartina; pollen analysis

\section{Introduction}

Coastal wetlands are globally valued for their protection of land through reducing wind and wave energy, as well as being integral to marine communities through the provision of organic matter $[1,2]$. This century, coastal wetlands have been shown to be important carbon sinks [3], being amongst the highest carbon storing ecosystems globally $[4,5]$ contributing a disproportionately high sink for enhanced greenhouse gas emissions relative to the wetland global area $[3,6]$. The largest component of organic carbon found in coastal wetland systems is in the sediment profile [7-9] where organic carbon accumulates from the decomposition of leaves, stems and root matter of wetland vegetation during sediment accretion $[10,11]$. The ability of coastal wetlands to store carbon has provided an additional conservation value in a period when the vulnerability of these unique ecosystems is increasing due to degradation, erosion, reclamation, and accelerated sea level rise [3,7,9,12-14].

Saltmarshes provide a long-term carbon sink owing to increasing sediment volume over long timescales, with carbon sequestered from roots, rhizomes, leaves and stems of marsh grasses, in the water-saturated conditions of the sediment profile [15]. Of all coastal wetlands, the most significant data gaps remain for sediment carbon evaluation in tidal saltmarshes, even though they are likely 
to hold the highest long-term rate of carbon accumulation in sediment [16]. The amount of carbon found in sediment is variable based on local site conditions, and species $[7,10,12]$. Further research is required to improve global assessments of tidal saltmarsh carbon stocks, particularly in the southern hemisphere where very little data is available $[7,12]$.

Analysis of saltmarsh data from sites between 28.4 and $55.5^{\circ} \mathrm{N}$ found an average carbon density in saltmarshes to be $0.039 \pm 0.003 \mathrm{~g} \mathrm{~cm}^{-3}$ [7]. Belowground stocks of Southeast mainland Australia saltmarshes $29-37^{\circ} \mathrm{S}$ showed little variation with latitude [5], geomorphic settings rather being a control on carbon sequestration variation through influences on sedimentary factors. Fluvial settings showed more than two times higher carbon stocks relative to marine settings, attributed to finer sediment grain sizes [5]. Assessment of carbon stocks across mainland Australia also found that landward fluvial tidal marsh sites showed twice the amount of organic carbon relative to seaward, marine sites [17].

Limited research has however been published on saltmarsh carbon storage from the Southern hemisphere, with early data showing only one study reporting research further south than $32^{\circ}$ in latitude $[7,12,16]$. In the last five years, understanding of variation in carbon stocks in NSW and Queensland has increased [5,18-20], as well as in Victoria [5,21], and data from all mainland Australian states and territories were analysed in the last 12 months to show an average of $77.9 \mathrm{Mg}$ organic carbon (OC) per hectare (range 8.9-603.7 Mg C ha ${ }^{-1}$ ), in the top $30 \mathrm{~cm}$ of marsh sediment [17]. There is a need to collect data on organic carbon stocks in areas unrepresented in previous studies such as Tasmania [17], as there remains no assessment from this southern Australian Island State. There may be differences in southern hemisphere sites owing to different species assemblages, as well as geomorphic settings and catchment histories.

The aim of this study is to undertake an exploratory investigation into the sediment carbon store and carbon accretion rates of native and introduced estuarine saltmarsh species in Tasmania, the southernmost state of Australia at a latitude of $41^{\circ} 09^{\prime} \mathrm{S}$.

\section{Materials and Methods}

\subsection{Study Site}

Tasmania extends across a latitudinal range of $39^{\circ} 40^{\prime}-43^{\circ} 20^{\prime} \mathrm{S}$, and has a total saltmarsh area of $47 \mathrm{~km}^{2}$ [22]. Tidal ranges are micro-tidal [23], but of greater range on the north coast, where saltmarsh extents are also greater relative to the south and west coasts. The Rubicon Estuary on the central north coast of Tasmania $\left(41^{\circ} 09^{\prime} \mathrm{S}, 146^{\circ} 33^{\prime} \mathrm{E}\right.$; Figure 1) has a total catchment area of $262 \mathrm{~km}^{2}$, an overall low topographic relief and a tidal range of $2.1 \mathrm{~m}$ [24]. The mean monthly temperature range is $8.3-17^{\circ} \mathrm{C}$, and the mean precipitation is $773 \mathrm{~mm} \mathrm{a}^{-1}$ with a winter maximum [25]. The climatic conditions within the greater Rubicon estuary area have been historically favorable to land use changes such as intensive agriculture, that have resulted in a high sediment supply [26,27].

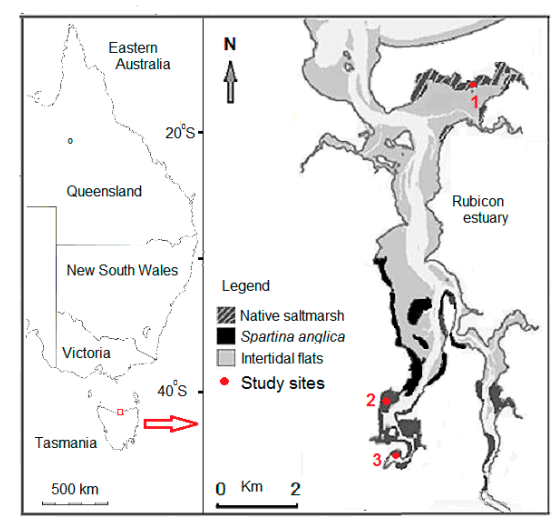

Figure 1. Location of the Rubicon estuary, Tasmania, showing intertidal zones and saltmarsh study sites. 
Common saltmarsh species in Tasmania include Sarcocornia quinqueflora, which is restricted to Australasia. The plant has a high tolerance to saline soils and waterlogged conditions, and inhabits the lower saltmarsh zone [28]. Juncus kraussii is also a common saltmarsh species in Tasmania, and is not as salt tolerant as S. quinqueflora so inhabits the high saltmarsh zone [28]. Juncus species occur across Europe and America, but J. kraussii only occurs in the southern hemisphere in Australia, New Zealand and South Africa [29], where it inhabits the landward fringe of the saltmarsh. Spartina anglica originated in England, and was intentionally introduced last century in Europe, the USA, China, Australia, and to Tasmania in the 1940s [11]. Spartina can occupy both low and high saltmarsh zones, and is now considered to be a vigorous invasive species in Tasmania [30]. The Rubicon is the second largest infestation in Australia, after the Tamar estuary located to the east of the Rubicon.

Sites were chosen to undertake an exploratory investigation of these saltmarsh communities dominated by a particular species in the Rubicon Estuary. Site 1 was located in native saltmarsh (Figure 1), in an estuarine bay protected area managed as a Spartina free zone. Site 2 was located in the upper estuary, in dense pioneer cover of introduced Spartina vegetation with no native saltmarsh species present. Site 3 was located on the western margin of the Rubicon estuary in dense, well-established Spartina vegetation (Figure 1).

\subsection{Sample Collection and Laboratory Analyses}

Two cores were collected at site 1, core 1.1 from J. kraussii vegetation, and core 1.2 from S. quinqueflora vegetation, and one core was collected each from each of sites 2 and 3 . A sidewall sampling peat corer was used to extract sediment cores, of $8.5 \mathrm{~cm}$ in diameter to a depth of approximately $0.6 \mathrm{~m}$. Compaction was negligible owing to the sidewall sample design of the corer. The cores were placed in a split plastic pipes, taped and wrapped securely for transportation to the analytical laboratory. Cores were carried horizontally at all times to prevent vertical compaction. In the laboratory, cores were opened in a horizontal position and sediment was sampled at $5 \mathrm{~cm}$ increments.

Grain size was determined using the Bouyoucos method [31], and 2 depths were analysed per core, from 13-15 cm to 40-42 cm. Carbon density has been shown to decline with depth [5,12,15], and hence particle size distribution from samples above $15 \mathrm{~cm}$ and below $40 \mathrm{~cm}$ may indicate potential trends. Samples were oven dried at $60^{\circ} \mathrm{C}$ for $48 \mathrm{~h}$, then any roots removed through a $1.18 \mathrm{~mm}$ sieve. Samples were placed in a microid flask shaker with the dispersing agent $5 \%$ sodium hexametaphosphate for $10 \mathrm{~min}$. Then samples were shaken in a volumetric flask with distilled water, and inverted to further disperse particles, and suspended solids measured with a hydrometer at $5 \mathrm{~min}$ and $2 \mathrm{~h}$.

For determination of organic carbon content, pre-treatment of $\mathrm{HCl}$ was used for the removal of inorganic carbon from the samples prior to the carbon analysis [32]. Subsamples were immersed in $6 \mathrm{~N}$ $\mathrm{HCl}$ to test for carbonates [32], and not to the entire sample, as $\mathrm{HCl}$ may dissolve part of the organic matter present within the sample, leading to an underestimation of the organic matter content [33]. Where effervescence was present, samples were immersed in $6 \mathrm{~N} \mathrm{HCl}$ for 10 min then rinsed 5 times with distilled water to remove remnant traces of $\mathrm{HCl}$ [32]. Samples not displaying effervescence were mixed and then divided by volume into $10 \mathrm{~mL}$ replicates for bulk density analysis [34]. After oven drying at $60^{\circ} \mathrm{C}$ for $72 \mathrm{~h}$ until a constant dry weight was obtained [11], samples were passed through a $425 \mu \mathrm{m}$ sieve to remove vegetation fragments before being ground into a fine powder using a mortar and pestle. Samples were then placed in a muffle furnace at $550{ }^{\circ} \mathrm{C}$ for $4 \mathrm{~h}$ [35]. Following air-drying, structural water accounts for only $2 \%$ of ignition loss in high clay content estuarine marsh soil [32].

To measure the concentration of carbon content of the sediment samples (\%), replicate samples from each core were prepared as above [32] and analysed using a Thermo Finnigan EA 1112 Series Flash Elemental Analyser, after being weighed to a precision of $0.1 \mu \mathrm{g}$. The Elemental Analyser measured the amount of carbon, hydrogen and nitrogen in the material by the combustion of small amounts (1-2 mg) of the sediment sample in pure oxygen and in the presence of catalysts at high temperature $\left(1000^{\circ} \mathrm{C}\right)$. The combustion products were separated by passing them through a packed 
column and quantified using a thermal conductivity detector. Carbon density was determined from the bulk density results and the elemental analysis carbon percentage results.

Carbon contained in catchment or estuary sediment has previously been estimated using published saltmarsh area data [12]. Areas of native and Spartina saltmarshes within the Rubicon Estuary have been recently mapped at 1:500 or less using spatial analysis [36,37]. Carbon content was calculated for the top $30 \mathrm{~cm}$ of sediment to enable comparison with that elsewhere $[12,16,17]$ using average results of carbon density $\left(\mathrm{g} \mathrm{cm}^{-3}\right)$ from cores from native marsh sites 1.1 and 1.2, average results for cores from Spartina sites 2 and 3, and areas of Spartina and native saltmarsh vegetation zones $[36,37]$.

\subsection{Vertical Accretion}

Short-term sediment accretion can be measured using sediment accretion above an inserted marker horizon $[12,16,18,19,38]$. Three replicate feldspar plots $(0.25 \mathrm{~m}$ by $0.25 \mathrm{~m})$ were established on the marsh at each site. The locations of plots were based on the following criteria: representation of the species, accessibility and location in an area that was prograding and not in an erosion zone as shown by topographic profiles. In areas with dense plant cover, feldspar clay was shaken through vegetation until the marsh surface was adequately covered to a depth of $5 \mathrm{~mm}$, feldspar plots were re-visited after 6 and 12 months [38], and the depth of accretion above the marker was measured to the nearest millimetre at three positions and averaged [12]. Samples were taken of the accumulated sediment above the feldspar horizon, and analysed to determine bulk density and to calculate a carbon density accumulation rate.

Pollen analysis was performed on the site $1.1 \mathrm{~J}$. kraussii core in order to calculate a long-term accretion rate, as no visible sediment had accreted on the feldspar plot after 6 and 12 months. The depth in a core at which an introduced species first appears can be used to date that level [11,39], allowing a net accretion rate above this to be calculated, for the time period subsequently elapsed. This approach was used in the Tamar estuary to calculate net accretion rates over the last few decades [11], using historical information on the introduction of Spartina. The dates of introduction of Spartina to the Rubicon estuary are not recorded, however, Pinus radiata plantations were established in the Rubicon catchment from 1968, within $30 \mathrm{~km}$ of the study sites. P. radiata first flowers at the age of 7 [40], and is wind-pollinated. Therefore, it is likely that abundant pine pollen would appear in the record in 1976. Ten samples at $5 \mathrm{~cm}$ increments from the core were prepared using the standard pollen concentration technique [41]. A known amount of spores of the exotic Lycopodium was added to allow determination of pollen concentration. Pollen grains were identified, and counted at each sample level until a count of $200 \mathrm{~g}$ was reached. Net vertical accretion was calculated using the depth of first pine pollen appearance divided by the time elapsed since.

\section{Results}

\subsection{Grain Size and Organic Matter}

Grain size distributions of sediments in cores are shown for all sites in Figure 2a, with all sites showing decreasing clay and increasing silt with depth. The up-estuary Spartina sites 2 and 3 (Figure 1) showed all results to be clay, while both cores at site 1 showed coarser results of a silty clay combination.

Organic matter content decreased with depth at all sites (Figure 2b). Site 1.2 (S. quinqueflora) and Site 3 (Spartina) showed the most even distribution of organic matter decreasing by less than $1 \%$ with depth. Site 1.1 (J. kraussii) showed a higher surface organic content $(3 \%)$, however, a lower mean organic content. Site 1.2 had the lowest mean organic content, while the loss-on ignition results from Spartina sites 2 and 3 were within $0.1 \%$ of each other (Table 1 ). 


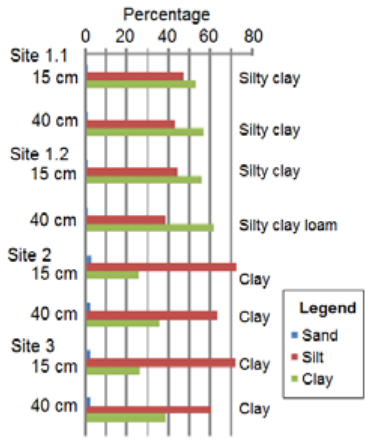

(a)

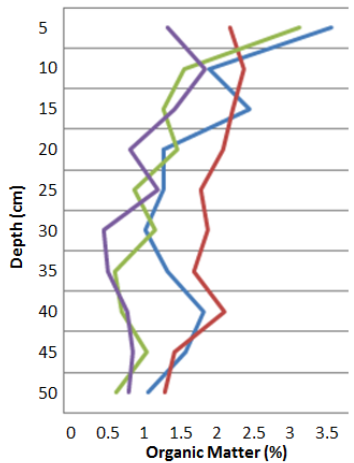

Organic Matter (\%)

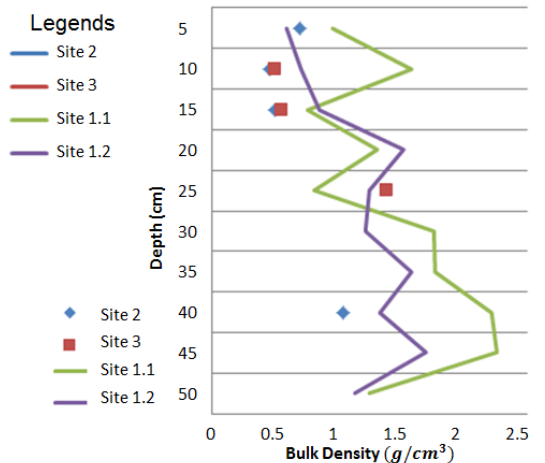

(b)

Figure 2. (a) Grain size results in percentages of sand, silt and clay, and texture classification; (b) Organic matter content and bulk density trends with depth from Rubicon estuary saltmarsh sites.

Table 1. Results from organic matter, bulk density, sediment carbon and carbon density determinations in the top $0.3 \mathrm{~m}$ of the cores from Rubicon estuary sites (mean $\pm \mathrm{SE}$ ).

\begin{tabular}{ccccc}
\hline Property & Site 1.1 & Site 1.2 & Site 2 & Site 3 \\
\hline Vegetation type & J. kraussii & S. quinqueflora & Spartina & Spartina \\
Organic matter $(\%)$ & $1.2 \pm 0.2$ & $1 \pm 0.13$ & $1.7 \pm 0.2$ & $1.8 \pm 0.1$ \\
Bulk density $\left(\mathrm{g} / \mathrm{cm}^{3}\right)$ & $1.47 \pm 0.17$ & $1.19 \pm 0.11$ & $0.68 \pm 0.08$ & $0.8 \pm 0.16$ \\
Sediment carbon $(\%)$ & $1.37 \pm 0.63$ & $0.78 \pm 0.24$ & $1.95 \pm 0.39$ & $2.6 \pm 0.17$ \\
Carbon density $\left(\mathrm{g} / \mathrm{cm}^{3}\right)$ & $0.023 \pm 0.006$ & $0.010 \pm 0.002$ & $0.017 \pm 0.001$ & $0.020 \pm 0.002$ \\
Vertical accretion $(\mathrm{mm} /$ year $)$ & 0.42 & 18 & 20 & 30 \\
Carbon accretion $\left(\mathrm{g} / \mathrm{cm}^{2} /\right.$ year $)$ & 0.015 & 0.022 & 0.034 & 0.055 \\
\hline
\end{tabular}

The bulk density results in each core showed an inverse relationship with organic matter content (Figure $2 \mathrm{~b}$ ), with values of $0.5-2.4 \mathrm{~g} \mathrm{~cm}^{-3}$ with depth. Bulk density was not calculated on all site 2 and 3 samples due to the pre-treatment of $\mathrm{HCl}$, restricting analysis of a trend with depth. No effervescence was observed in native marsh cores from site 1, while minor effervescence was observed in six of the subsamples from Spartina cores, most of these from site 2 (Figure 1).

\subsection{Sediment Carbon Results}

Percentage carbon results with depth showed carbon levels of $0.5 \%$ to $7.0 \%$, with decreasing carbon with depth at each site (Figure 3). Sites 2 and 3 both showed the most carbon stored throughout the sediment profile. However, site 1.1 (J. kraussii) showed the highest proportion of carbon in the surface sediment $(0-5 \mathrm{~cm})(7.16 \%)$.

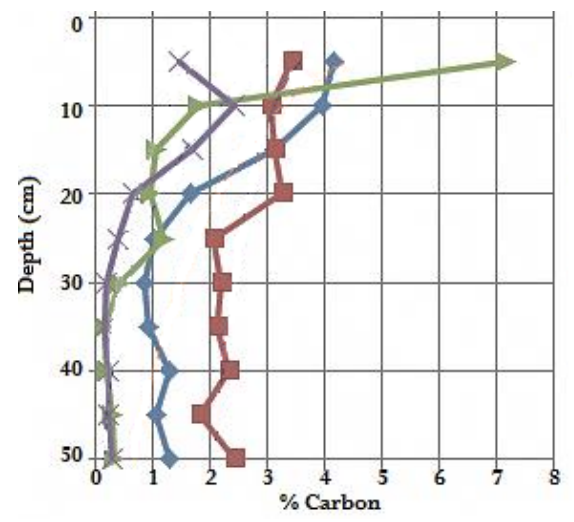

Figure 3. Relationship between percentage carbon with depth from each core. 
Carbon density results with depth in each core (Figure 4a) showed that the density of carbon was greater in non-native Spartina marsh (sites 2 and 3) relative to the native marsh site 1.2 with S. quinqueflora, but less than the native high marsh site 1.1 with J. kraussii (Table 1). The density of carbon decreased with depth in cores from all sites. The core results from each site showed twice the carbon density in native high marsh J. kraussii sediment (site 1.1), relative to low marsh native S. quinqueflora at site 1.2. The non-native species core results were consistent in carbon density at both sites 2 and 3.

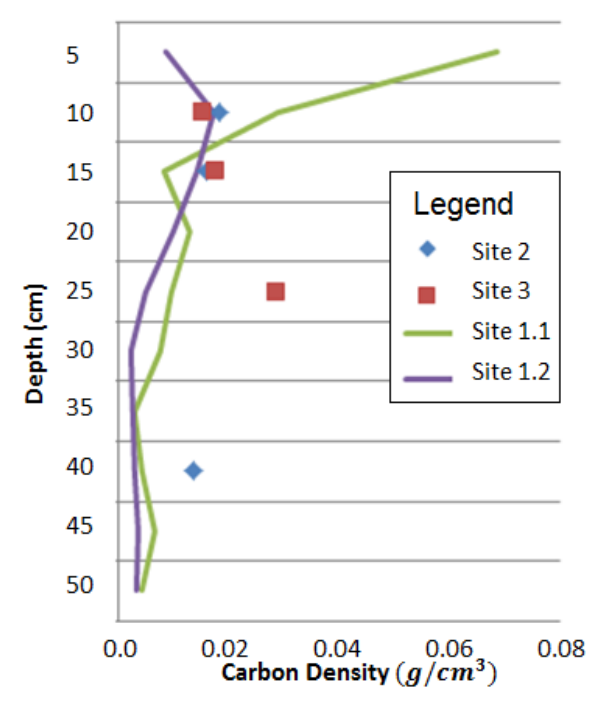

(a)

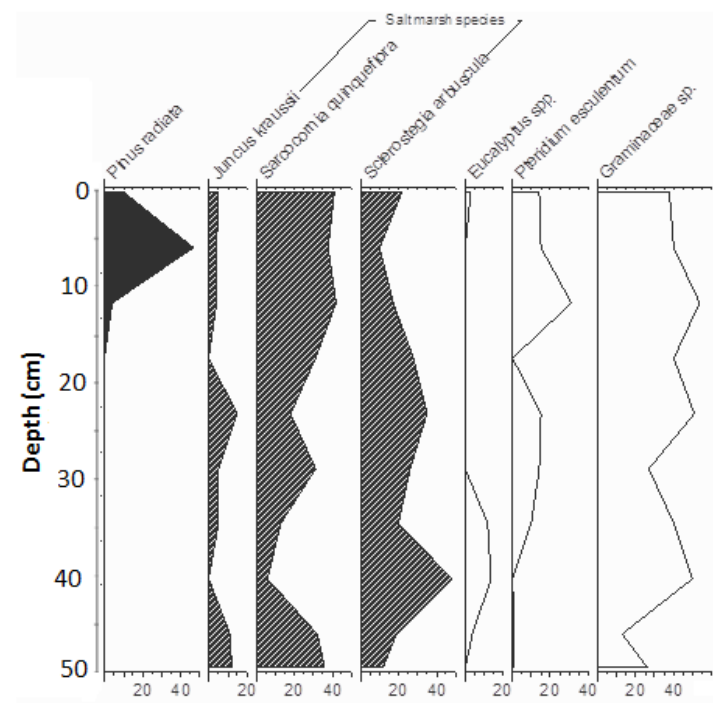

(b)

Figure 4. (a) Carbon density trends with depth in core samples from Rubicon estuary sites; (b) Pollen percentages with depth from the site 1.1 core.

Vertical accretion and carbon accumulation results from core results from each site (Table 1) showed that the native low marsh species, S. quinqueflora, at site 1.2 accumulated at a slower rate than at the Spartina sites. Based on the 12 months accretion data, Spartina at site 3 showed net sediment accumulation rates at $150 \%$ the rate of Spartina at site 2 . By contrast, the native high marsh species J. kraussii at site 1.1 showed $0 \mathrm{~mm} \mathrm{a}^{-1}$ vertical accretion over the 1 year study duration using the feldspar method. Results from the alternative technique adopted of pollen analysis from the core at site 1.1 are shown in Figure $4 \mathrm{~b}$, with several saltmarsh species represented and pine pollen appearing at $20 \mathrm{~cm}$ depth, with $40 \%$ abundance at $10 \mathrm{~cm}$ depth. Pine plantations were established in the catchment in 1968 and were likely flowering by 1976, hence indicating that long term sediment accretion at site 1.1 has been at a rate of $0.42 \mathrm{~mm} \mathrm{a}^{-1}$ (Table 1).

Spatial analysis data from the Rubicon estuary [36,37] for the area of this study (Figure 1) showed native saltmarsh to cover a total area of 39 hectares, with Spartina covering an area of 226 hectares in 2016 (Table 2). This area of Spartina is greater than previous estimates [42], and can be attributed to spread of Spartina in marginal sections such as site 2. An estuarine saltmarsh sediment carbon content was calculated based on the carbon density results (Table 2), showing variation according to native and introduced vegetation types and geomorphic settings.

Table 2. Below ground carbon stocks (upper $30 \mathrm{~cm}$ ) in the different saltmarsh species zones of the Rubicon estuary.

\begin{tabular}{cccc}
\hline Saltmarsh Species Zone & Area (ha) [36,37] & Carbon Store (Mg C) & Carbon Stock (Mg C ha ${ }^{-\mathbf{1}}$ ) \\
\hline Native saltmarsh & 39 & 1930 & 49.5 \\
Spartina & 226 & 12,543 & 55.5 \\
\hline
\end{tabular}




\section{Discussion}

All cores from this study showed a fining upwards trend of increased clay (Figure 2a), and also finer grain sizes closer to fluvial sources rather than the estuary mouth (Figures 1 and 2a), with all samples from the Spartina sites classified as clay sediments. Fluvially-dominated sites are found to have finer sediment sizes relative to marine-dominated sites [5]. Decreased grain size in sediments causes the sediment organic carbon to increase [5,43], owing to clay particles binding carbon molecules and reducing microbial breakdown [44].

The core results indicated organic matter in the top $30 \mathrm{~cm}$ of saltmarsh sediment to be higher in introduced Spartina sites relative to native saltmarsh in the Rubicon estuary (Figure 2b; Table 1), but lower relative to wetland sediment averages both globally and elsewhere in Australia [7]. The adjacent Tamar estuary located to the east of the Rubicon typically has $14-28 \%$ organic matter in Spartina sediment by comparison [11], determined using the same techniques as in this study. These low results from the Rubicon of $0.5-3.5 \%$ (Table 1) may be due to the high catchment sediment yield, with recent land use changes [26,27].

Carbon density results from the four cores analysed in this study from Rubicon estuary marshes (Figure 4a) indicated levels lower relative to the northern hemisphere, with analysis of sites between 28.4 and $55.5^{\circ} \mathrm{N}$ showing the global average carbon density for saltmarshes to be $0.039 \mathrm{~g} \mathrm{~cm}^{-3}$ [7], and also lower relative to NSW results from $38^{\circ} \mathrm{S}$, of $0.03 \mathrm{~g} \mathrm{~cm}^{-3}$ [13]. Carbon density results were also at the lower range of results from locations of similar mean annual temperature [7], and lower than the fluvially-dominated saltmarshes of NSW $\left(29-37^{\circ} \mathrm{S}\right)[5]$, which may be owing to the higher latitude of the Rubicon, and higher sediment accretion rates with mostly inorganic content (Figure $2 b$, Table 1). Further study of carbon density in Tasmanian saltmarshes in different estuaries and using replicated cores across species zones with statistical analysis could confirm these apparent trends.

The percentage carbon as shown by our results was also consistently lower than marshes studied elsewhere, ranging between $0.17 \%$ and $7.16 \%$, likely influenced by grain size differences (Figure 2a). In marshes of the eastern USA, carbon percentages were found to range between $5.95 \%$ and $10.81 \%$ depending on marsh type [45], and in marshes of NSW, Australia carbon percentages were found to range between $3.7-5.9 \%$ for $J$. kraussii and $2.1-4.8 \%$ for S. quinqueflora [46]. This study, as indicated from one core per site, found lower carbon percentage ranges for the same species studied in NSW, of $0.17-7.16 \%$ for $J$. kraussii and $0.17-2.44 \%$ for S. quinqueflora (Figure 3).

It is likely that the overall lower levels of carbon found in the Rubicon estuary are due to higher net accretion rates (Table 1), dominated by inorganic sediment derived from the catchment. Net accretion rates under J. kraussi saltmarsh in NSW were found to be $1.74 \pm 0.13 \mathrm{~mm} \mathrm{a}^{-1}$, and under Sarcocornia $0.78 \pm 0.18 \mathrm{~mm} \mathrm{a}^{-1}$ [18], far lower than rates found in the Rubicon (Table 1). Over $35 \%$ of the Rubicon catchment area is used for agriculture, and a further $25 \%$ is in plantation forestry, with estimates of $0.3-5.3 \mathrm{Mg} \mathrm{ha}^{-1} \mathrm{a}^{-1}$ of soil erosion from cropped and cultivated land [26,27]. Catchments in Tasmania have been relatively recently converted from native vegetation to productive land uses compared with many other locations in the world. Net accretion rates under Spartina in the adjacent Tamar estuary since its introduction have been $8.7-52.4 \mathrm{~mm} \mathrm{a}^{-1}$ [11], indicating these higher regional trends. Carbon density results from this study are similar to saltmarsh research elsewhere, where high levels of inorganic sediments reduce organic matter accumulation [7,11,47].

However, the carbon accumulation rates as shown by core results from each of the sites within the Rubicon estuary indicated equivalence to global rates. Sites 2 and 3 showed carbon accumulation rates higher than the global average of $0.021 \mathrm{~g} \mathrm{~cm}^{-3} \mathrm{a}^{-1}$ (including mangroves and saltmarshes) [7], while site 1.2 was similar in accreting $0.022 \mathrm{~g} \mathrm{~cm}^{-3} \mathrm{a}^{-1}$ (Table 1).

Belowground carbon stocks of the Rubicon estuary saltmarsh (Table 2) were indicated to be low in comparison to all nine fluvial and marine saltmarsh sites analysed across NSW (29-37 $\mathrm{S})$ [5], the mean carbon stock of saltmarshes globally [3], and results of carbon stocks across mainland Australia of average 78 (range 9-604) $\mathrm{Mg} \mathrm{OC} \mathrm{ha}{ }^{-1}$ using the comparative measurement of the top $30 \mathrm{~cm}$ [17]. The Rubicon carbon evaluation of $49-55 \mathrm{Mg} \mathrm{C} \mathrm{ha}^{-1}$ (Table 2) is most similar to results from sites in 
South Australia [17]. These carbon sequestration stores are of useful financial value in contribution to greenhouse mitigation according to recent auctions held by Australia's Clean Energy Regulator [17].

This study indicates that the introduced Spartina, owing to its extent over $85 \%$ of the 265 ha of Rubicon saltmarsh area is likely contributing the majority of the sediment carbon store, estimated to be $12,543 \mathrm{Mg}$ C (Table 2). Extensive coring of Spartina marshes in the adjacent Tamar estuary [11] showed Spartina to have accumulated $>50 \mathrm{~cm}$ of sediment since its introduction last century in established areas and with mudflats beneath these deposits, suggesting that the $30 \mathrm{~cm}$ sediment depths analysed in the Rubicon are likely accumulated under Spartina. The finer grain sizes of sediment that Spartina has accumulated ([11], Figure 2a) would be an important influence.

Carbon accumulation rates and palaeo-environmental information for individual peatlands are often inferred from analyses conducted on a single core [48]. Analysis of 323 cores from 66 saltmarsh locations (several with up to three studies) across mainland Australia [17] included nine locations with just one core contributing to analysis of carbon sequestration trends. This Rubicon study contributes information from two cores from native marsh and two from Spartina marsh, however, the results could be confirmed by more extensive sampling, combined with statistical analysis. Studies on carbon storage from marshes in Victoria used three cores at each location [17], or four from each vegetation zone [5], and within-site differences in carbon accumulation and the complex responses of proxy indicators to both allogenic and autogenic changes [48] are improved by such practice.

Further work could also include pollen analysis of more cores, to confirm that the vegetation contributing to $30 \mathrm{~cm}$ depth of carbon accumulation, or $100 \mathrm{~cm}$ as analysed in other studies, is derived by the species presently on the surface. This study showed that this was the case for one native marsh site (Figure $4 \mathrm{~b}$ ), though the pollen of that species is generally poorly preserved so has reduced representation relative to other pollen. Pollen analysis of sediment cores is a low cost but time-consuming technique, where one diagram can require some months of careful laboratory analyses [49], however, this study confirms its potential value in confirming the sources of historic blue carbon stores. Dating of significant layers in the analysed levels of sediment [41] could also show the timeframe.

\section{Conclusions}

After its deliberate introduction last century, Spartina is now viewed in Australia as a problem invasive species $[50,51]$ owing to its impacts on aquaculture, and threats to the ecological integrity of estuarine wetlands of international importance $[11,30]$. As a result, control and eradication strategies have been undertaken [30,42], such as limiting further spread onto mudflats that are important wader habitats. This study indicates that Spartina may have a previously unrealized value as a useful carbon sink, which could influence future management attitudes particularly towards the two largest infestations of this species in Australia of the Rubicon and Tamar estuaries, both in northern Tasmania. Largescale removal of Spartina has been shown in the Tamar to likely result in sediment erosion [11], and this study indicating its value as a carbon sink adds to caution in considering its large-scale removal from shorelines where it is now well-established. Future research could confirm the effects of invasive Spartina on increasing saltmarsh carbon sequestration in Tasmania.

Blue carbon of wetland sediment is of high value to greenhouse mitigation [17], and this study contributes saltmarsh sediment carbon information from the most southerly latitude reported to date. Overall, this study shows that the contribution of high latitude saltmarshes to carbon sequestration is of value, and the focus of most studies on lower latitude saltmarshes could be beneficially expanded to better understand trends.

Author Contributions: J.C.E. and K.M.B. conceived and designed the study; K.M.B. performed the fieldwork and laboratory analyses, and J.C.E. largely wrote this paper.

Acknowledgments: This research was supported by the Governor of Tasmania's Environment Scholarship. The authors thank three anonymous peer reviewers whose comments allowed improvements to the article.

Conflicts of Interest: The authors declare no conflict of interest. 


\section{References}

1. Boorman, L.A. Salt marshes-present functioning and future change. Mangroves Saltmarshes 1999, 3, $227-241$. [CrossRef]

2. Chmura, G.L. What do we need to assess the sustainability of the tidal salt marsh carbon sink? Ocean Coast. Manag. 2011. [CrossRef]

3. Duarte, C.M.; Losada, I.J.; Hendriks, I.E.; Mazarrasa, I.; Marbà, N. The role of coastal plant communities for climate change mitigation and adaptation. Nat. Clim. Chang. 2013, 3, 961-968. [CrossRef]

4. Mitra, S.; Wassmann, R.; Vlek, P. An appraisal of global wetland area and its organic carbon stock. Curr. Sci. 2005, 8, 25-35.

5. Kelleway, J.J.; Saintilan, N.; Macreadie, P.I.; Ralph, P.J. Sedimentary factors are key predictors of carbon storage in SE Australian saltmarshes. Ecosystems 2016, 19, 865-880. [CrossRef]

6. Mitsch, W.J.; Bernal, B.; Nahlik, A.M.; Mander, Ü.; Zhang, L.; Anderson, C.J.; Jørgensen, S.E.; Brix, H. Wetlands, carbon, and climate change. Landsc. Ecol. 2013, 28, 583-597. [CrossRef]

7. Chmura, G.L.; Anisfeld, S.C.; Cahoon, D.R.; Lynch, J.C.; Laffoley, D.; Baxter, J. Global carbon sequestration in tidal, saline wetland soils. Glob. Biogeochem. Cycles 2003. [CrossRef]

8. Bouillon, S.; Borges, A.V.; Castaneda-Moya, E.; Diele, K.; Dittmar, T.; Duke, N.C.; Kristensen, E.; Lee, S.Y.; Marchand, C.; Middelburg, J.J.; et al. Mangrove production and carbon sinks: A revision of global budget estimates. Glob. Biogeochem. Cycles 2008, 22. [CrossRef]

9. Donato, D.C.; Kauffman, J.B.; Murdiyarso, D.; Kurnianto, S.; Stidham, M.; Kanninen, M. Mangroves among the most carbon-rich forests in the tropics. Nat. Geosci. 2011, 4, 293-297. [CrossRef]

10. Craft, C. Freshwater input structures soil properties, vertical accretion, and nutrient accumulation of Georgia and U.S. tidal marshes. Limnol. Oceanogr. 2007, 52, 1220-1230. [CrossRef]

11. Sheehan, M.R.; Ellison, J.C. Intertidal morphology change following Spartina anglica introduction, Tamar Estuary, Tasmania. Estuar. Coast. Shelf Sci. 2014, 149, 24-37. [CrossRef]

12. Howe, A.J.; Rodriguez, J.F.; Saco, P.M. Surface evolution and carbon sequestration in disturbed and undisturbed wetland soils of the Hunter estuary, southeast Australia. Estuar. Coast. Shelf Sci. 2009, 84, 75-83. [CrossRef]

13. Elsey-Quirk, T.; Seliskar, D.M.; Sommerfield, C.K.; Gallagher, J.L. Salt marsh carbon pool distribution in a Mid-Atlantic lagoon, USA: Sea level rise implications. Wetlands 2011, 31, 87-99. [CrossRef]

14. Crosby, S.C.; Sax, D.F.; Palmer, M.E.; Booth, H.S.; Deegan, L.A.; Bertness, M.D.; Leslie, H.M. Salt marsh persistence is threatened by predicted sea-level rise. Estuar. Coast. Shelf Sci. 2016, 181, 93-99. [CrossRef]

15. Connor, R.F.; Chmura, G.L.; Beecher, C.B. Carbon accumulation in Bay of Fundy saltmarshes: Implications for restoration of reclaimed marshes. Glob. Biogeochem. Cycles 2001, 15, 943-954. [CrossRef]

16. Pidgeon, E. Carbon sequestration by coastal marine habitats: Important missing sinks. In The Management of Natural Coastal Carbon Sinks; Laffoley, D., Grimsditch, G., Eds.; IUCN: Gland, Switzerland, 1999; pp. 47-51, ISBN 978-2-8317-1205-5.

17. Macreadie, P.I.; Ollivier, Q.R.; Kelleway, J.J.; Serrano, O.; Carnell, P.E.; Lewis, C.E.; Atwood, T.B.; Sanderman, J.; Baldock, J.; Connolly, R.M.; et al. Carbon sequestration by Australian tidal marshes. Sci. Rep. 2017, 7, 44071. [CrossRef] [PubMed]

18. Kelleway, J.J.; Saintilan, N.; Macreadie, P.I.; Baldock, J.A.; Ralph, P.J. Sediment and carbon deposition vary among vegetation assemblages in a coastal salt marsh. Biogeoscience 2017, 14, 3763-3779. [CrossRef]

19. Brown, D.R.; Conrad, S.; Akkerman, K.; Fairfax, S.; Fredericks, J.; Hanrio, E.; Sanders, L.M.; Scott, E.; Skillington, A.; Tucker, J.; et al. Seagrass, mangrove and saltmarsh sedimentary carbon stocks in an urban estuary; Coffs Harbour, Australia. Reg. Stud. Mar. Sci. 2016, 8, 1-6. [CrossRef]

20. Hayes, M.A.; Jesse, A.; Hawke, B.; Baldock, J.; Tabet, B.; Lockington, D.; Lovelock, C.E. Dynamics of sediment carbon stocks across intertidal wetland habitats of Moreton Bay, Australia. Glob. Chang. Biol. 2017, 23, 4222-4234. [CrossRef] [PubMed]

21. Lewis, C.J.E.; Carnell, P.E.; Sanderman, J.; Baldock, J.A.; Macreadie, P.I. Variability and vulnerability of coastal 'Blue Carbon' stocks: A case study from Southeast Australia. Ecosystems 2017, 1-17. [CrossRef]

22. Zann, L.P. Our Sea, Our Future: Major Findings of the State of the Marine Environment Report for Australia; Great Barrier Reef Marine Park Authority: Townsville, Australia, 1995; ISBN 9780642173911. 
23. Short, A.D. Beaches of the Tasmanian Coast and Islands; Sydney University Press: Sydney, Australia, 2006; ISBN 1-920898-12-3.

24. Edgar, G.J.; Barrett, N.S.; Graddon, D.J. A Classification of Tasmanian Estuaries and Assessment of Their Conservation Significance Using Ecological and Physical Attributes, Population and Land Use; Marine Research Laboratories, University of Tasmania: Hobart, Australia, 1999; ISBN 0724647546.

25. Bureau of Meteorology. Available online: www.bom.gov.au/climate/averages/tables/cw_091126.shtml (accessed on 21 November 2017).

26. Cotching, W.E. A review of the challenges for long term management of krasnozems in Australia. Aust. J. Soil Water Conserv. 1995, 8, 18-27.

27. Sims, C.; Cotching, W. Turbidity and sediment loads from selected catchments in north-west Tasmania. Nat. Res. Manag. J. 2000, 3, 8-14.

28. Adam, P. Australian saltmarshes in global context. In Australian Saltmarsh Ecology; Saintalin, N., Ed.; CSIRO Publishing: Collingwood, Australia, 1999; pp. 1-22, ISBN 9780643093713.

29. Greenwood, M.E.; MacFarlane, G.R. Effects of salinity and temperature on the germination of Phragmites australis, Juncus kraussii, and Juncus acutus: Implications for estuarine restoration initiatives. Wetlands 2006, 26, 854-861. [CrossRef]

30. Sheehan, M.R.; Ellison, J.C. Tidal marsh erosion and accretion trends following invasive species removal, Tamar Estuary, Tasmania. Estuar. Coast. Shelf Sci. 2015, 164, 46-55. [CrossRef]

31. Bowles, J.E. Engineering Properties of Soils and Their Measurement, 2nd ed.; McGraw-Hill Publishing Co.: New York, NY, USA, 1986.

32. Craft, C.B.; Seneca, E.D.; Broome, S.W. Loss on ignition and Kjeldahl Digestion for estimating organic carbon and total Nitrogen in estuarine marsh Soils: Calibration with dry combustion. Estuaries 1991, 14, 175-179. [CrossRef]

33. Schumacher, B. Methods for the Determination of Total Organic Carbon (TOC) in Soils and Sediments; Office of Research and Development, US. Environmental Protection Agency: Las Vegas, CA, USA, 2002.

34. Bengtsson, L.; Enell, M. Chemical analysis. In Handbook of Holocene Palaeoecology and Palaeohydrology; Berglund, E.B., Ed.; The Blackburn Press: Caldwell, NJ, USA, 1986; Volume 13, pp. 423-455, ISBN 978-1930665804.

35. Heiri, O.; Lotter, A.F.; Lemcke, G. Loss on ignition as a method for estimating organic and carbonate content in sediments: Reproducibility and comparability of results. J. Paleolimnol. 2001, 25, 101-110. [CrossRef]

36. Prahalad, V. Atlas of Coastal Saltmarsh Wetlands in the Cradle Coast Region of Tasmania; Cradle Coast NRM: Burnie, Tasmania, Australia, 2016.

37. Prahalad, V. Coastal Saltmarsh Wetland Asset Mapping: Technical Report; Cradle Coast NRM: Burnie, Tasmania, Australia, 2016.

38. Chmura, G.L.; Coffey, A.; Crago, R. Variation in surface sediment deposition on salt marshes in the Bay of Fundy. J. Coast. Res. 2001, 17, 221-227.

39. Ellison, J.C. Pollen evidence of Late Holocene mangrove development in Bermuda. Glob. Ecol. Biogeogr. Lett. 1996, 196, 315-326. [CrossRef]

40. Fernández, M.P.; Cornejo, B. Is the first flowering event and corresponding maturity phase in trees related to radial wood density changes? Trees 2016, 30, 859-870. [CrossRef]

41. Ellison, J.C. Long-term retrospection on mangrove development using sediment cores and pollen analysis. Aquat. Bot. 2008, 89, 93-104. [CrossRef]

42. Rice Grass Advisory Group. Strategy for the Management of Rice Grass (Spartina anglica) in Tasmania, Australia; Department of Primary Industries, Water and Environment: Hobart, Australia, 2002.

43. Jiménez, J.J.; Lal, R.; Rosso, R.O.; Leblanc, H.A. The soil organic carbon in particle-size separates under different regrowth forest stands of northeastern Costa Rica. Ecol. Eng. 2008, 34, 300-310. [CrossRef]

44. Sparrow, L.A.; Belbin, K.; Doyle, R.B. Organic carbon in the silt + clay fraction of Tasmanian soils. Soil Use Manag. 2006, 22, 219-220. [CrossRef]

45. Loomis, M.J.; Craft, C.B. Carbon sequestration and nutrient (nitrogen, phosphorus) accumulation in river-dominated tidal marshes, Georgia, USA. Wetland Soils 2010, 74, 1028-1037. [CrossRef]

46. Clarke, P.J.; Jacoby, C.A. Biomass and above-ground productivity of saltmarsh plants in South-eastern Australia. Aust. J. Mar. Freshwater Res. 1994, 45, 1521-1528. [CrossRef] 
47. Patrick, W.H.; DeLaune, R.D. Subsidence, accretion, and sea level rise in south San Francisco Bay marshes. Limnol. Oceanogr. 1990, 36, 1389-1395. [CrossRef]

48. Chapman, P.J.; Dargie, G.; Dooling, G.P.; Gee, C.; Holden, J.; Kelly, T.; McKendrick-Smith, K.A.; Morris, P.J.; Noble, A.; Palmer, S.M.; et al. Questioning ten common assumptions about peatlands. Mires Peat 2017, 12, $1-23$.

49. Ellison, J.C. Biogeomorphology of mangroves. In Coastal Wetlands: An Ecosystem Integrated Approach; Wolanski, E., Cahoon, D., Perillo, G.M.E., Eds.; Elsevier Science: Amsterdam, The Netherlands, 2018, in press.

50. Boon, P.I.; Allen, T.; Rosengren, N.; Sinclair, S.; White, M.; Yugovic, J. Coastal wetlands of Victoria, south-eastern Australia: Providing the inventory and condition information needed for their effective management and conservation. Aquat. Conserv. Mar. Freshw. Ecosyst. 2014, 25, 454-479. [CrossRef]

51. Laegdsgaard, P. Ecology, disturbance and restoration of coastal saltmarsh in Australia: A review. Wetl. Ecol. Manag. 2006, 14, 379-399. [CrossRef]

(C) 2018 by the authors. Licensee MDPI, Basel, Switzerland. This article is an open access article distributed under the terms and conditions of the Creative Commons Attribution (CC BY) license (http:/ / creativecommons.org/licenses/by/4.0/). 